\title{
THE LEGALIZATION OF INDUSTRIAL HEMP AND WHAT IT COULD MEAN FOR INDIANA'S BIOFUEL INDUSTRY
}

\author{
Nicole M. Keller
}

Over thirty countries around the world have a legal industrial hemp industry; the United States is not one of them. ${ }^{1}$ Each of these countries have realized the amazing potential of this one plant as an efficient input source for many industries including, but not limited to, food products, cosmetics, paper, automotive parts, clothing, and biofuel. ${ }^{2}$ These industries provide a steady source of income and thousands of jobs for people all over the world. ${ }^{3}$ The use of hemp as the primary input makes the processes and resulting products environmentally safe and even beneficial. ${ }^{4}$ In the United States, countless studies have shown the benefits of hemp. ${ }^{5}$ Many states have conducted their own feasibility studies examining what hemp can do for them. ${ }^{6}$ In this time of economic turmoil and budget deficits, states are looking for ways to diversify and expand their current industries. They are also looking for cheaper, smarter, more environmentally friendly ways to produce products in their current industries. Some states are finding that industrial hemp offers an answer. ${ }^{7}$ The production of industrial hemp products is a new industry in itself. $^{8}$ Additionally, industrial hemp can help replace, and possibly eliminate, the need for limited resource inputs in the

1. Countries Growing Hemp, ARIz. INDUS. HEMP COUNCIL, http://azhemp.org/Archive/ Package/Countries/countries.html (last visited Aug. 17, 2013).

2. Hemp Information, Hemp Facts, NorTh AMERICAN Industrial Hemp Council, http://www.naihc.org/hemp-information/286-hemp-facts (last visited Aug. 17, 2013); see also JEAN M. RAWSON, CRS REPORT FOR CONGRESS: HEMP AS AN AGRICULTURAL COMMODITY 4 (2005) [hereinafter CRS REPORT], available at http://www.fas.org/sgp/crs/ RL32725.pdf.

3. Joseph B. Gonsalves, U.N. Conference on Trade and Dev., An Assessment of the Biofuels Industry in India at 12, 37 (2006), available at http://www.unctad.org/en/docs/ ditcted20066_en.pdf.

4. Dr. Eric C. Thompson, et al., Economic Impact of Industrial Hemp in Kentucky, CrR. FOR BUS. AND ECON. RESEARCH, UNIV. OF KY. 1 (1998), available at http://www.votehemp.com/ PDF/hempstudy.pdf.

5. See, e.g., Kimball Christensen \& Andrew Smith, Does the Use of Cannabis Species for the Production of Biodiesel and Ethanol, Result in Higher Yields of Ethanol Than Competing Cellulotic Crops, Including Zea Mays?, UnIV. OF WASH., DEP'T OF BIOLOGY

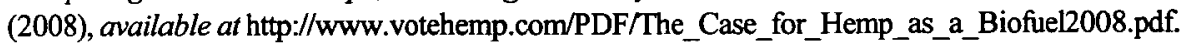

6. Id.; see also, Daryl T. Ehrensing, Feasibility of Industrial Hemp Production in the United States Pacific Northwest, EXTENSION SERV. OR. STATE UNIV. (1998), available at http://extension.oregonstate.edu/catalog/html/sb/sb681/.

7. Thompson, et al., supra note 4 , at iii.

8. See generally id. 
paper and fuel industries. ${ }^{9}$ In response to these findings, several states have passed legislation allowing for the growth of industrial hemp under state licensing schemes. ${ }^{10}$ However, the states are meeting resistance at the federal level. As a result, despite the benefits of industrial hemp and the states' desire to take advantage of their newly enacted laws, no industrial hemp has yet to be grown. ${ }^{11}$

This Note begins with a discussion of what industrial hemp is and is not. Next, the Note describes in further depth the various uses for industrial hemp and its potential impact on certain industries, with a specific look at hemp as a source of biofuel. Following this section is a discussion of hemp history and laws in the United States and Canada, with a comparison of the two approaches. Next, the Note briefly examines the economic impact of the current US hemp laws on trade and commerce on a national level. The Note then takes a more micro approach by looking at the state laws emerging in favor of legalizing industrial hemp, including an examination of statutory and case law. Then, the Note focuses on Indiana law and its biofuel industry. A comparison is made between environmental conditions in Indiana and surrounding states that have legalized the production of industrial hemp. Next, the Note argues that Indiana's biofuel goals could be better met by growing industrial hemp instead of taking corn out of the food supply to meet biofuel production needs. Finally, the Note argues that, in order for states to take advantage of the benefits of industrial hemp, the United States must change the classification of industrial hemp, and ultimately model its regulations of the industrial hemp industry after the Canadian model.

\section{WHAT IS INDUSTRIAL HEMP?}

There is a common, and unfortunate, misconception surrounding industrial hemp in American society. The industrial hemp plant, despite its inability to have any psychoactive effects, ${ }^{12}$ is often confused with its cousin marijuana. Both plants are members of the species Cannabis Sativa; however, each plant represents the opposite spectrum of the plant's capabilities. ${ }^{13}$ "Cannabis is the only plant genus that contains the unique

9. Id. at 36 .

10. U.S. State Industrial Hemp Regulation, VOTEHEMP.COM, http://www.votehemp.com/ legislation.html (last visited Aug. 17, 2013).

11. NORML Statement on the Cultivation of Industrial Hemp, NORML.ORG, http:// norml.org/marijuana/industrial/item/introduction-5 (last visited Aug. 17, 2013).

12. David P. West, Ph.D., Hemp and Marijuana: Myths \& Realities, NORTH AMERICAN INDUSTRIAL HEMP COUNCIL (1998), http://naihc.org/hemp_information/content/hemp.mj.html (last visited Mar. 17, 2013).

13. Id. at 3. 
class of molecular compounds called cannabinoids. ${ }^{14}$ Many cannabinoids have been identified, but two preponderate: THC . . and CBD."15 The type of Cannabis known as marijuana has long been recognized for its medicinal and recreational properties. ${ }^{16}$ This is due to its levels of delta-9 tetrahydrocannabinol (THC), the psychoactive component in the plant. ${ }^{17}$ Marijuana typically contains relatively high levels of THC, ranging from five to twenty percent, ${ }^{18}$ and low levels of CBD, the antipsychoactive cannabinoid..$^{19}$ Industrial hemp, on the other hand, "contains less than 1 percent" 20 of THC, with the normal range under $.5 \%,{ }^{21}$ and high levels of $\mathrm{CBD} .^{22}$ Because industrial hemp has very low levels of THC, "no one could get high from smoking it." ${ }^{, 23}$ In fact, the high levels of CBD in hemp actually block the high associated with smoking marijuana. ${ }^{24}$ "Hemp, it turns out, is not only not marijuana; it could be called 'antimarijuana.",25

In addition to the psychoactive differences between the two variations of Cannabis, the cultivation characteristics set them apart as well. Granted, the seeds and leaves of marijuana and industrial hemp are strikingly similar in appearance, but they are easy to distinguish from each other when grown for their respective purposes. ${ }^{26}$ Marijuana is grown for its flower, which comes from the female plant. ${ }^{27}$ The goal is to maximize the plant's flowering potential, so plants are spaced widely to allow room to grow. ${ }^{28}$ By contrast, industrial hemp is generally grown for its fibrous stalk. ${ }^{29}$ Spacing is extremely close to encourage height and fiber production and

14. Id. at 7 .

15. Id. at 7-8.

16. Legal Issues, ARIZ. INDUS. HEMP COUNCIL, http://azhemp.org/Archive/Package/ Legal/legal.html (last visited Aug. 17, 2013).

17. NORML Statement on the Cultivation of Industrial Hemp, supra note 11.

18. Hemp Defined, NORTH AMERICAN INDUSTRIAL HEMP COUNCIL, http://www.naihc.org/ hemp-information/289-hemp-defined (last visited Mar. 17, 2013).

19. West, supra note 12.

20. U.S. DEP'T OF AGRIC. ECON. RESEARCH SERV., INDUSTRIAL HEMP IN THE UNITED STATES: STATUS AND MARKET POTENTIAL, at iii (Jan. 2000), available at http://www.ers.usda.gov/ publications/ages001E/ages001E.pdf.

21. Legal Issues, supra note 16.

22. West, supra note 12.

23. Legal Issues, supra note 16.

24. Id.

25. Id.

26. Valarie L. Vantreese, Industrial Hemp: Global Markets and Prices 4 (1997), available at $\mathrm{http}: / / \mathrm{www}$. votehemp.com/PDF/hemp97.pdf.

27. Marijuana Science-Based Information for the Public, UNIV. OF WASH. ALCOHOL AND DRUG ABUSE INST., http://adai.uw.edu/marijuana/factsheets/potency.htm (last visited Aug. 17, 2013).

28. Vantreese, supra note 26 , at 4.

29. Id.; D. Michelle Domke, Hemp Case, 7 TED CASE STUDIES 398 (1997), available at http://wwwl.american.edu/ted/hemp.htm. 
discourage leaf production. ${ }^{30}$ Furthermore, industrial hemp is harvested much earlier than its cousin marijuana; ${ }^{31}$ therefore, it is relatively easy to identify illegal fields past a certain date. ${ }^{32}$ In fact, over thirty countries are able to tell the difference between the two plants, and are able to benefit from an industrial hemp industry. ${ }^{33}$

\section{THE New Billion Dollar CROP ${ }^{34}$}

These countries, which have been able to distinguish between hemp and marijuana, are able to take advantage of an enormous renewable resource that boosts their economies and lessens their country's impact on the global environment. Hemp "can be used to produce more than 25,000 products, ranging from dynamite to cellophane." 35 This statement was made in 1938 when Popular Mechanics released an article toting the wonders of industrial hemp, claiming it was the new billion dollar crop. The article "further state[d] that increased hemp production 'will displace imports of raw material and manufactured products' and call[ed] hemp the 'standard fiber of the world."”36 That was in 1938. With today's advanced technologies, it is highly likely that the number of uses exceeds 25,000 products. ${ }^{37}$ In fact, some sources claim that over 50,000 products can be made from this single plant. ${ }^{38}$ Among the 50,000 products are "textiles, paper, paints, clothing, plastics, cosmetics, foodstuffs, insulation, animal feed, ${ }^{, 39}$ biodegradable industrial products such as fiberglass, replacement for wood products, biofuel, and detergents. ${ }^{40}$ For a majority of these products, the fibrous stalk of the hemp plant is used. However, the seeds are also an excellent source of oil, varnishes, body care products, detergents, and biofuel. In other words, the entire hemp plant has a use; nothing goes to

30. Vantreese, supra note 26 , at 4.

31. West, supra note 12. See also NORML Statement on the Cultivation of Industrial Hemp, supra note 11 (industrial hemp's planting cycle); Hemp Defined, supra note 18 (industrial hemp's planting cycle).

32. See Hélèna Katz, Hemp Legalization Sparks Growth of New Industries, AMERICAN NEwS SERVICES (June 1, 2000), available at http:/www.berkshirepublishing.com/ans/ HTMView.asp?parItem $=\mathrm{S} 031000480 \mathrm{~A}$.

33. Id.

34. New Billion Dollar Crop, POPUlaR MECH. MAgazine (Feb. 14, 1938), available at http://www.globalhemp.com/1938/02/new-billion-dollar-crop.html.

35. Id.

36. Hemp History, HEMP-SISTERS.COM, http://www.hemp-sisters.com/Information/history.htm (last visited Aug. 17, 2013).

37. See Jeff Meints, The Hemp Plant, Humankind's Savior - 50,000 Uses and Counting, (Jan. 23, 2007, 11:32 AM), http://www.voteindustrialhemp.com/.

38. $I d$.

39. NORML, Statement on the Cultivation of Industrial Hemp, supra note 11.

40. See A Treasure Plant, HEMPUSA.ORG, https://www.hempusa.org/index.php/productarticles-category/hemp-information/a-treasure-plant.html (last visited Aug. 17, 2013). 
waste.

Many countries now have active industries utilizing industrial hemp to their benefit. For example, China has large hemp paper and textile industries. $^{41}$ In 2009 Zhang Jianchun, Director General of China's Hemp Research Centre in Beijing, said,

Expanded production of hemp ... offers enormous benefits for China. First, it would provide a major new source of fibre for the textile industry, reduce dependency on cotton and, in the process, free large areas of cotton-growing land for food production. In addition, hemp cultivation would generate extra income for millions of small-scale farmers in some of the country's poorest rural areas. ${ }^{42}$

Three years later, "[China] is the largest exporter of hemp paper and [hemp] textiles. ${ }^{, 43}$ It seems that, at least in China, Popular Mechanics' tout that hemp would become the "standard fiber of the world" becoming a reality as the Chinese increasingly replace fibers such as cotton with industrial hemp. ${ }^{45}$ Additionally, another large producer of hemp products is Canada, which supplies the world with a variety of hemp food products. ${ }^{46}$ Canada's hemp food industry is growing, and Canadian farmers are benefiting from the US government's refusal to legalize the crop. ${ }^{47}$

Among the products derivable from the industrial hemp plant, and the product most relevant to this Note, is hemp as a biofuel. In a time of high gas prices, political instability, and increasing concerns over the environmental effects of fossil fuel consumption, it is natural to seek an alternative. Globally, the use of biofuels as an alternative to petroleum products is gaining momentum. ${ }^{48}$ The United States alone consumed approximately 11.7 million gallons of ethanol in $2011^{49}$ and over 549

41. Countries Growing Hemp, supra note 1.

42. Fibre Stories: Hemp's Future in Chinese Fabrics, U.N. Food AND AGRICULTURE ORGANIZATION: INT'L YEAR OF NATURAL FIBRES (2009), http://www.naturalfibres2009.org/ en/stories/hemp.html.

43. Countries Growing Hemp, supra note 1.

44. New Billion Dollar Crop, supra note 34.

45. Fibre Stories, supra note 42.

46. CAN. Hemp TRAde Alliance, http://www.hemptrade.ca/ (last visited Aug. 17, 2013).

47. Katz, supra note 32.

48. See Candace Lombardi, World Biofuel Use Expected to Double by 2015, CNET (Sept. 30, 2009, 9:31 AM), http://news.cnet.com/8301-11128_3-10364139-54.html.

49. Monthly U.S. Fuel Ethanol Production/Demand, RENEWABLE Fuels Ass'N, http://ethanolrfa.org/pages/monthly-fuel-ethanol-production-demand (last visited Aug. 17, 2013). 
million gallons of biodiesel in the first 9 months of $2011 .^{50}$ In Canada, hemp biofuel research is underway to produce cellulosic ethanol. ${ }^{51}$ Cellulosic ethanol is ethanol produced from the non-food parts of feedstock and is a more efficient source of energy. ${ }^{52}$ Currently, the majority of feedstock for biofuels comes from corn, soybeans, or wheat. ${ }^{53}$ However, in addition to being an inefficient source of fuel, the diversion of these commodities for fuel production is at the expense of the world food supply. ${ }^{54}$ The United States has recognized the issue and has "announced a $\$ 510$ million initiative meant to spur development of a new US bio-fuel industry that utilizes non-food crops[.] ${ }^{, 55}$ The initiative is meant to examine sources such as algae or wood chips; ${ }^{.56}$ however, there is a more efficient source: industrial hemp.

"When compared to other plant species of active interest in biofuel production, Hemp derives $100 \%$ more cellulose than species under active investigation." ${ }^{.57}$ Furthermore, "[h]emp is Earth's number one biomass resource; it is capable of producing 10 tons per acre in four months." Hemp biomass fuel products require a minimal amount of specialization and processing and "[t]he hydrocarbons in hemp can be processed into a wide range of biomass energy sources, from fuel pellets to liquid fuels and gas." 59 These facts alone make industrial hemp the ideal source for both ethanol and biodiesel production. Yet, industrial hemp, in addition to its fibrous plant matter, also produces seeds wherein lies a rich source of hemp

50. Erin Voegele, Latest EIA Numbers Show Biodiesel Consumption Is on the Rise, BIODIESEL MAGAZINE (Dec. 29, 2011), http://biodieselmagazine.com/articles/8255/latest-eianumbers-show-biodiesel-consumption-on-the-rise.

51. Michael Bachara, Canada: Research for the Production of Cellulosic Ethanol from Sustainable Feedstock Begins, HEMP NEws (Feb. 26, 2010 11:23 PM), http://www.hemp.org/ news/content/canada-research-cellulosic-ethanol-sustainable-feedstock.

52. See Ethanol, TeXas STATE ENERGY CONSERVATION OfFice, http://www.seco.cpa. state.tx.us/energy-sources/biomass/ethanol.php\#cellulosic (last visited Aug. 17, 2013).

53. See generally Kevin Kerr, Ethanol: The Truth About This 'Alternative' Fuel, THE DAILY RECKONING, http://dailyreckoning.com/alternative-fuel-the-truth-about-ethanol/ (last visited Aug. 17, 2013).

54. See id.; see also Holly Jessen, Hemp Biodiesel: When the Smoke Clears, BIODIESEL MAGAZINE (Jan. 24, 2007),

http://www.biodieselmagazine.com/articles/1434/hemp-biodiesel-when-the-smoke-clears;

Fibre Stories, supra note 44 (saying hemp will provide food security because it will be grown in areas that do not displace food production).

55. Devin Dwyer, White House Seeks New US Bio-Fuel Industry Not Based on Corn, ABC NEws (Aug. 16, 2011), http://abcnews.go.com/blogs/politics/2011/08/white-houseseeks-new-us-bio-fuel-industry-not-based-on-com/.

56. $I d$.

57. Christensen \& Smith, supra note 5.

58. Hemp: Food Fuel Fiber Medicine Industry, HEMPCAR TRANSAMERICA, http://www.hempcar.org/hempfacts.shtml (last visited Aug. 17, 2013).

59. Hemp Facts, ARIz. INDUS. HEMP COUNCIL, http://azhemp.org/Archive/Package/ Facts/facts.html (last visited Aug. 17, 2013). 
oil, and this oil can also be used for fuel. ${ }^{60}$

Industrial hemp's fuel capabilities and desirability is further enhanced by the fact that "[i]ndustrial hemp can be grown in most climates and on marginal soils. It requires little or no herbicide and no pesticide[.] ${ }^{\prime 61}$ The hemp plant is also known to improve soil conditions for rotational crops, ${ }^{62}$ and it is a clean-burning fuel, contributing no greenhouse gases. ${ }^{63}$ Yet, industrial hemp is not seriously considered as a feedstock input, ${ }^{64}$ largely because industrial hemp is illegal to grow in the United States.

\section{INDUSTRIAL HEMP HISTORY IN THE UNITED STATES}

Industrial hemp was not always illegal in the United States. ${ }^{65}$ In fact, before 1937 it was grown and manufactured into many products. ${ }^{66}$ The public sentiment surrounding the plant was social acceptance of a staple in the American household. ${ }^{67}$ It was used most often for clothing, paper, rope, and lamp oil. ${ }^{68}$ Respected presidents were proponents of industrial hemp: "George Washington and Thomas Jefferson both grew hemp. Ben Franklin owned a mill that made hemp paper. Jefferson drafted the Declaration of Independence on hemp paper[,]"69 and "Abraham Lincoln use[d] hemp-seed oil to fuel his household lamps." ${ }^{, 70}$ But in 1937, right when mechanical processes that would turn hemp into a truly industrialized commodity were about to explode on the American scene, ${ }^{71}$ Congress passed the Marihuana Tax Act of $1937 .^{72}$ The Act was aimed at eliminating the use of marijuana as a drug but had the effect of making all industrial hemp varieties illegal as well. $^{73}$

60. Biodiesel, The CAMPaign for the Restoration and Regulation of Hemp, http://crrh.org/biodiesel/ (last visited Aug. 17, 2013).

61. Tim Castleman, Hemp Biomass for Energy, FUEL AND FIBER Co., (2001), available at http://icearth.drupalgardens.com/content/hemp-biomass-energy-tim-castleman-fuel-andfiber-company.

62. Thompson, et al., supra note 4, at 52; See infra note 254 .

63. Id. at 7 .

64. Advanced Ethanol, ReNEwABLE Fuels Assoc., http://www.ethanolrfa.org/pages/ cellulosic-ethanol (last visited Aug. 17, 2013).

65. See Seaton Thedinger, Prohibition in the United States: International and U.S. Regulation and Control of Industrial Hemp, 17 Colo. J. INT'L ENVTL. L. \& PoL'Y 419, 42526 (2006).

66. $I d$.

67. See generally id.

68. See Hemp History, supra note 36.

69. History, ARIZ. INDUS. HEMP COUNCIL, http://azhemp.org/Archive/Package/History/ history.html (last visited Aug. 17, 2013).

70. Hemp History, supra note 36.

71. New Billion Dollar Crop, supra note 34.

72. Thedinger, supra note 65 , at 426.

73. History, supra note 69. 
The Act placed a $\$ 1$ tax on anyone who "imports, manufactures, produces, compounds, sells, deals in, dispenses, prescribes, administers, or gives away marihuana." ${ }^{74}$ Although legislative history shows that industrial hemp was not an intended target of the law, and "Harry J. Anslinger, Commissioner of the Federal Bureau of Narcotics (FBN) (the predecessor to the Drug Enforcement Administration (DEA)), told the Senate Committee that those in the domestic industrial hemp industry 'are not only amply protected under this act, but they can go ahead and raise hemp just as they have always done it[, $]^{\prime \prime 75}$ the wording of the law effectively prohibited industrial hemp cultivation. ${ }^{76}$ Specifically, $\S 1$ (b) of the Act says,

The term "marihuana" means all parts of the plant Cannabis sativa L., whether growing or not; the seeds thereof; the resin extracted from any part of such plant; and every compound, manufacture, salt, derivative, mixture, or preparation of such plant, its seeds, or resin- but shall not include the mature stalks of such plant, fiber produced from such stalks, oil or cake made from the seeds of such plant, any other compound, manufacture, salt, derivative, mixture, or preparation of such mature stalks (except the resin extracted therefrom), fiber, oil, or cake, or the sterilized seed of such plant which is incapable of germination. ${ }^{77}$

It is clear that Congress tried to exclude industrial hemp from the legislation (i.e. "but shall not include the mature stalks of such plant" "), but for practical purposes there is no way for a farmer to produce the "mature stalks of such plant" without growing "the seeds thereof." After the passage of the Act, hemp farmers were confused about the impact the Act would have on their operations. ${ }^{80}$ Letters were sent to the Federal Bureau of Narcotics asking what should be done about the hemp that had been harvested but not yet sold. ${ }^{81}$ People wanted to know if even having it was a violation of the new law. ${ }^{82}$ The letters also urged the Bureau to conduct

74. Tara Christine Brady, The Argument for the Legalization of Industrial Hemp, 13 SAN JOAQUIN AGRIC. L. REV. 85, 89 (2003).

75. Id.

76. $I d$.

77. Marihuana Tax Act of 1937, Pub. L. No 75-238, §1(b), 50 Stat. 551, 552 (repealed 1970), available at $\mathrm{http}: / / \mathrm{www}$.druglibrary.org/schaffer/hemp/taxact/mjtaxact.htm.

78. Id.

79. $I d$.

80. See generally, John Craig Lupien, UnRaveling an American Dilemma: The DeMONIZATION OF MARIHUANA, Ch. 4 (1995), available at http://www.iahushua.com/T-LJ/DMH-4.html.

81. Id.

82. Id. 
research on the benefits of the hemp plant. ${ }^{83}$ Officials, unsure about the exact properties of hemp, gave conflicting answers and enforced the new law inconsistently. ${ }^{84}$ Moreover, there was never any formal research to determine if hemp was a viable crop for big industry and if it could be produced without the psychoactive effect found in marijuana. ${ }^{85}$ Thus, for some time, the hemp industry mostly died in America. ${ }^{86}$

Several years later in 1942, at the request of the Department of Agriculture, US farmers were enlisted to grow hemp in an effort to support the war. ${ }^{87}$

Despite the existence of the Marihuana Tax Act of 1937, the result of the "Hemp for Victory" Campaign was that "thousands of farmers grew hundreds of thousands of acres of hemp for wartime needs." However, by the end of WW II, the government's allowance of industrial hemp cultivation also ended and by 1957, "prohibitionists had reasserted a total ban on hemp production."

Time passed, and American culture changed and evolved throughout the 1960's when drug use escalated amidst the country's freedom movement. ${ }^{89}$ As a result of the increased use of recreational drugs, in 1970 Congress passed the Controlled Substances Act, which lays out definitions, offenses, and charges related to narcotic drugs in the United States. ${ }^{90}$ In it, Cannabis sativa is defined just as it was in the Marihuana Tax Act of 1937, lumping industrial hemp into the category of Schedule I: Hallucinogenic Substances, ${ }^{91}$ despite hemp not having high enough THC levels to have any narcotic effect. ${ }^{92}$

Over the past ten years, many states have realized the economic and environmental potential of industrial hemp and have passed legislation legalizing its cultivation. ${ }^{93}$ However, because of its narcotic classification a

83. $I d$.

84. Id.

85. See generally, LUPIEN, supra note 80 .

86. Id.

87. Brady, supra note 74 , at 90 .

88. Id.

89. See West, supra note 12. See also generally, Mortal Journey, The 1960's Hippie Counter Culture Movement, Mortal Journey.com (Feb. 13, 2013, 10:05:34 AM), http://www.mortaljourney.com/2011/03/1960-trends/hippie-counter-culture-movement.

90. See generally, CONTROLLED SUBSTANCES ACT, 21 U.S.C. $\S \S 802-889$, available at http://www.fda.gov/regulatoryinformation/legislation/ucm148726.htm.

91. Id. $\S \S 802(16), 812(\mathrm{c})($ Schedule I)(c)(10).

92. West, supra note 12.

93. EARTHFIRST.ORG, Hemp, http://www.earthfirst.org/hemp.htm (last visited Aug. 16, 2013). 
DEA permit is also required. ${ }^{94}$ Unfortunately, the DEA has refused to grant any permits, ${ }^{95}$ which makes production still illegal at the federal level and effectively voids any efforts the states have taken to legalize industrial hemp.

On February 14, 2013, "[Senator] Rand Paul and Senate Republican Leader Mitch McConnell, both of Kentucky, joined Oregon Democratic [Senators] Jeff Merkley and Ron Wyden in introducing legislation to allow American farmers to cultivate and profit from industrial hemp." ${ }^{.96}$ The legislation, which is a companion bill to H.R. 525, also known as the "Industrial Hemp Farming Act of 2013" would explicitly exclude industrial hemp from the definition of marijuana in the Controlled Substances Act, thus giving regulation of the crop to the States.$^{97}$ Currently the bill is in the first stage of the legislative process. ${ }^{98}$ The existence of this bill demonstrates the importance and potential of the industrial hemp industry. It illustrates the people's desire to move away from the draconian enforcement of outdated laws that fail to change and adapt with the demands of society.

\section{INDUSTRIAL HEMP IN CANADA}

In order to assess where the United States is on the world scene regarding industrial hemp, a look to other countries is necessary. Specifically, and most relevant to the United States, a comparison to Canadian hemp law is revealing and promises a viable regulation scheme which could be adopted in the United States.

Industrial hemp history in Canada follows a pattern familiar to the United States. ${ }^{99}$ Prior to 1938 , industrial hemp production was legal and encouraged in Canada. ${ }^{100}$ It served much of the same purpose as it did in the United States, primarily serving industries committed to producing rope, textiles, paper, and fuel. ${ }^{101}$ Then in 1937, the United States passed the

94. Brady, supra note 75 , at 85 . See also NORML Statement on the Cultivation of Industrial Hemp, supra note 11.

95. Brady, supra note 75 , at 90 .

96. Sens. McConnell and Paul Co-sponsor Industrial Hemp Legislation, PAUL.SENATE.Gov (Feb. 14, 2013), http://www.paul.senate.gov/?p=press_release\&id=707.

97. Id.

98. Industrial Hemp Farming Act of 2013, S. 359, 113th Cong. (2013-2014), available at http://thomas.loc.gov/cgi-bin/bdquery/z?d113:s.00359:.

99. See generally, Gov'T OF MAN., Manitoba Agriculture, Food and Rural Initiatives: Background of Industrial Hemp, http://www.gov.mb.ca/agriculture/crops/hemp/bko02s00.html (last visited Aug. 16, 2013).

100. Id.

101. HeALTH CAN., Frequently Asked Questions - Why Did the Government Change Its Laws, http://www.hc-sc.gc.ca/hc-ps/substancontrol/hemp-chanvre/about-apropos/faq/indexeng.php\#a7 (last visited Aug. 16, 2013) [hereinafter $F A Q$ ]. 
Marihuana Tax Act of 1937, and Canada followed suit in 1938 passing The Opium and Narcotics Control Act. ${ }^{102}$ The Act, similar to the US Act, was aimed at reducing recreational marijuana use but had the effect of eliminating industrial hemp cultivation. ${ }^{103}$

Sixty years later, however, the US and Canadian laws on industrial hemp diverged and in 1998, "the Canadian government legalized the growth of industrial hemp under license from Health Canada." 104 In coming to this decision, the Canadian government initially authorized research on industrial hemp to see if it would be a viable crop. ${ }^{105}$ The results affirmed that industrial hemp could "successfully [be] grown in Canada as a separate entity from cannabis (marijuana)." ${ }^{106}$ Armed with this knowledge and aware of the concerns regarding the difficulty of distinguishing between the two varieties of cannabis, Health Canada implemented some very stringent regulatory and licensing requirements to ensure strain autonomy and compliance with other federal laws. ${ }^{107}$

In deciding to legalize and regulate industrial hemp, Canada analyzed the plants' impact and wrestled with how the plant could be assimilated into Canadian society without infringing upon current laws. ${ }^{108}$ The result was the Regulatory Impact Analysis Statement (RIAS). ${ }^{109}$ The RIAS explains Canada's thought process when faced with the decision on whether or not to legalize industrial hemp. ${ }^{110}$ It lays out the regulations and explains why Canada chose to regulate the way it did. ${ }^{111}$ Health Canada analyzed three options: 1) strict compliance with drug laws - no legalization; 2) legalization with regulation; or 3) free market legalization - no regulation. ${ }^{112}$ Ultimately, option 2 was chosen. ${ }^{113}$ In coming to that decision, Health Canada set out mandatory criteria and then measured how well each option fit the criteria. ${ }^{114}$ According to the RIAS,

Each option was assessed using the following criteria:

102. Gov'T OF MAN, supra note 100.

103. Id.

104. Katz, supra note 32.

105. CRS REPORT, supra note 2, at 3.

106. FAQ, supra note 101 .

107. See Industrial Hemp Regulations (Controlled Drugs and Substances Act), SOR/98156 (Can.), available at http://laws-lois.justice.gc.ca/eng/regulations/SOR-98-156/.

108. See generally, HEALTH CAN. REgUlatory IMPACt ANALYSIS STATEMENT 1, (1998), available at http://www.hc-sc.gc.ca/hc-ps/alt_formats/hecs-sesc/pdf/pubs/precurs/rias1089/ rias1089-eng.pdf.

109. Id.

110. Id. at 5-6.

111. Id.

112. Id. at 6-7.

113. HEALTH CAN., supra note 108 , at 7.

114. Id. 
Mandatory criteria

- The option must be in conformity with the authorities contained in the CDSA and comply with Canada's international obligations.

- The option must not facilitate the production of illicit drugs.

- The option must provide an appropriate means of control (compliance).

\section{Screen criteria}

- The option must not hinder trade.

- The option must not be an undue burden on government and industry.

- The option must be responsive to future needs.

- The option must not undermine public confidence. ${ }^{115}$

Under option 2 - legalization with regulation - Health Canada amended Canada's Controlled Drugs and Substances Act by adding Industrial Hemp Regulations. ${ }^{116}$

The Canadian regulation method is a three-step process: application, licensing, and cultivation. ${ }^{117}$ First, the potential grower must apply for a license issued by Health Canada. ${ }^{118}$ The application is an extremely detailed process. A potential license holder must reside in Canada and must submit an application, which includes: name, address, phone number, date of birth, certificate of incorporation (if the applicant is a corporation), the activity hoping to be licensed, import/export/transportation documents (if applicable), the address of the place where the industrial hemp will be stored and sold (and indicating which form of industrial hemp will be at each address), the type of cultivar or variety of industrial hemp to be grown, the number of hectares of hemp grown for seed/grain/fiber, the GPS coordinates of each type of production and an indication on a map of where at each site each type is situated, etc. ${ }^{119}$ The requirement list is long, and it is tailored depending on the use for which hemp is grown, be it seed, fiber, or grain. ${ }^{120}$

Once the grower submits an application, Health Canada determines

115. Id.

116. Id. at 8.

117. Industrial Hemp Regulations, supra note 107.

118. Id. ("application" link under "licensing and authorization" link).

119. Id.

120. Id:; Industrial Hemp Regulations, supra note 107. 
whether to approve and issue a license or not. ${ }^{121}$ The requirements for approval are also strict and set up to ensure that each grower is in compliance with the regulations. ${ }^{122}$ Once a license is issued, the regulations continue with cultivation. ${ }^{123}$ Cultivation is allowed "only in the specified region, using an approved variety, specified on the license. Every person legally cultivating industrial hemp must submit samples of their crop to a licensed and accredited laboratory to ensure that the THC level is at or below $0.3 \%$, according to procedures outlined in the ... [regulations]." Other restrictions, such as not being able to grow industrial hemp within one kilometer of a school and requirements that all industrial hemp must be in a locked container or facility, ${ }^{125}$ illustrate Canada's acknowledgement of the potential risks associated with the legalization of industrial hemp, as well as its commitment to compliance with other Canadian laws. ${ }^{126}$

\section{ECONOMIC IMPACT OF US HEMP LAWS}

The legalization of industrial hemp in Canada introduced a new industry for Canada's citizens. ${ }^{127}$ The hemp industry is growing. ${ }^{128}$ In fact, some companies are reporting fifty percent business growth every year since $1998 .{ }^{129}$ Canada is quickly becoming a large player on the global hemp products scene. ${ }^{130}$ Primary industrial hemp exports from Canada include hemp seed, hemp fiber, and hemp oil, with about $60 \%$ of Canadian hemp exports going to the United States in 2010. ${ }^{131}$ According to the Hemp Industries Association (HIA), "the retail value of North American hemp food, vitamin and body care products was in the range of $\$ 121$ to $\$ 142$ million in 2010. When clothing, auto parts, building materials and other non-food or body care products are included, the HIA estimates that the total retail value of U.S. hemp products is about $\$ 419$ million.,"132

However, the true value of US hemp consumption is higher. Because

121. Id. ("issuance" link).

122. Id.

123. Id. ("cultivation" link).

124. Anthony Cortilet, MinN. DeP'T. OF Agric., Industrial Hemp Report (2010), available at $\mathrm{http}: / / \mathrm{www}$. votehemp.com/PDF/MN-legrpt-hemp.pdf.

125. Id.

126. See HeAlTh CAN., supra note 108 , at 5-6.

127. Gov'T OF MAN., supra note 99.

128. Rita Trichur, The 'Snicker Factor' Aside, Hemp Is Serious Business, THE GlOBE AND MAIL (July 10, 2011), http://www.theglobeandmail.com/report-on-business/the-snickerfactor-aside-hemp-is-serious-business/article $586400 /$.

129. Id.

130. Id.

131. Ray Hansen, Industrial Hemp Profile, AGRIc. MKTG. RES. CTR., http://www.agmrc.org/ commodities_products/fiber/industrial_hemp_profile.cfm (last updated Aug. 2012).

132. Id. 
of US hemp laws, American consumers must pay more for the hemp products they demand. Direct import costs and tariffs drive prices up. ${ }^{133}$ Additionally, greater delivery distances require more gas, resulting in higher prices. ${ }^{134}$ When products are priced too high, certain members of society are unable or unwilling to buy them and, in the case of industrial hemp, benefit from them. ${ }^{135}$ Demand is therefore skewed; whereas, if the United States had a legal industrial hemp industry and no longer needed to import the products, price would be down (sans extra import/tariff/fuel costs), and, assuming a normal demand curve, demand would go up. ${ }^{136}$ As demand increases, more producers enter the market, further driving price down. ${ }^{137}$ The result is lower prices to the American consumer and more Americans benefiting and consuming industrial hemp products from American farmers and businesses. ${ }^{138}$ Overall, this combination results in a higher value for industrial hemp products to the American economy. Yet even though the industry as it stands is still in the growth phase, ${ }^{139}$ US farmers and businesses are unable to capitalize on this new source of economic growth.

\section{INDUSTRIAL HEMP AND EMERGING STATE LAWS}

Many states, however, are trying to capitalize on the new industrial hemp market. Currently, "thirty-one states have introduced pro-hemp legislation and nineteen have passed legislation; nine (Hawaii, Kentucky, Maine, Maryland, Montana, North Dakota, Oregon, Vermont and West Virginia) have removed barriers to its production or research."140 Despite the growing interest and action taken by the states, federal law preempts all legislation they have passed. Therefore, with the exception of a small test field in Hawaii, ${ }^{141}$ no industrial hemp has actually been grown. ${ }^{142}$

Two states are of particular interest to this Note. First is North Dakota, where hemp farmers filed a suit against the DEA in Monson $v$. Drug Enforcement Agency ${ }^{143}$ arguing that as hemp farmers under North

133. See generally N. GREgoRY MANKIW, EsSENTIALS of ECONOMICS (Alex von Rosenberg, ed., Thomson South-Western) (4th ed. 2007).

134. Id.

135. Id.

136. Id.

137. Id.

138. Id.

139. See Allen St. Pierre, Hope for Industrial Hemp? Group Of Senators Seeking Legislative Sanity, NORML BLOG (Aug. 6, 2012), http://blog.norml.org/2012/08/06/hopefor-industrial-hemp-group-of-senators-seeking-legislative-sanity/.

140. U.S. State Industrial Hemp Regulation, supra note 10.

141. CoRTILET, supra note 124.

142. Id.

143. Monson v. Drug Enforcement Agency, 522 F. Supp. 2d 1188, 1191 (D. N.D. 2007). 
Dakota's industrial hemp statute they could not be prosecuted under the federal Controlled Substances Act. ${ }^{144}$ The Note will also look at Kentucky's industrial hemp regulations and then review a feasibility study on growing hemp in Kentucky.

\section{A. Monson v. Drug Enforcement Agency}

In 2007, David Monson and Wayne Hauge brought suit in North Dakota against the DEA. ${ }^{145}$ Monson and Hauge are farmers in North Dakota who had been granted valid licenses in that state under North Dakota's regulatory statute, N.D. Cent.Code $\$ 4-41-01$, to grow industrial hemp for commercial purposes. ${ }^{146}$ Initially, the North Dakota statute required that farmers must obtain a permit from the DEA to grow industrial hemp. ${ }^{147}$ However, once it became clear that the DEA was going to treat Monson and Hauge's application as one seeking to grow marijuana, a controlled substance, the North Dakota legislature changed the statute, removing the requirement to seek DEA approval. ${ }^{148}$ However, despite this change, the DEA still possessed Monson and Hauge's application and continued to process it. ${ }^{19}$ The DEA requested more information from the farmers, but instead of supplying it, the farmers filed suit seeking a declaratory judgment that industrial hemp was not covered by the definition of marijuana as a Schedule 1 controlled substance and therefore not subject to federal regulation. ${ }^{150}$

The North Dakota statute reads,

Industrial hemp (cannabis sativa 1.), having no more than three-tenths of one percent tetrahydrocannabinol, is recognized as an oilseed. Upon meeting the requirements of section 4-41-02, any person in this state may plant, grow, harvest, possess, process, sell, and buy industrial hemp (cannabis sativa 1.) having no more than three-tenths of one percent tetrahydrocannabinol. ${ }^{151}$

Monson and Hauge's argument rests on the fact that under the North Dakota statute industrial hemp is defined as Cannabis Sativa L., "having not

144. Id. at 1194. See also generally, 21 U.S.C. $\S \S 802-889$; N.D. CENT. CODE ANN. §441-01 (West 2011).

145. Monson, 522 F. Supp. 2d at 1194.

146. Id. at 1195.

147. Id. at 1194.

148. Id.

149. Id.

150. Id.

151. N.D. CENT. CODE ANN. \$4-41-01 (West 2011). 
more than three-tenths of one percent tetrahydrocannabinol." 152 However, the Controlled Substances Act (CSA) defines marijuana as,

[A]ll parts of the plant Cannabis sativa L., whether growing or not; the seeds thereof; the resin extracted from any part of such plant; and every compound, manufacture, salt, derivative, mixture, or preparation of such plant, its seeds or resin. Such term does not include the mature stalks of such plant, fiber produced from such stalks, oil or cake made from the seeds of such plant, any other compound, manufacture, salt, derivative, mixture, or preparation of such mature stalks (except the resin extracted therefrom), fiber, oil, or cake, or the sterilized seed of such plant which is incapable of germination. ${ }^{153}$

The court in Monson pointed out that the CSA makes no mention of THC content in the definition of marijuana; therefore, regardless of how North Dakota defines the plant, industrial hemp fits clearly within the definition set out in the CSA. ${ }^{154}$

The Monson case embodies the core problem industrial hemp activists seek to resolve: industrial hemp's inclusion in the definition of marijuana, a Schedule 1 controlled substance under the CSA. ${ }^{155}$ Activists argue that Congress did not intend to include industrial hemp in the definition because the definition excludes

the mature stalks of such plant, fiber produced from such stalks, oil or cake made from the seeds of such plant, any other compound, manufacture, salt, derivative, mixture, or preparation of such mature stalks (except the resin extracted therefrom), fiber, oil, or cake, or the sterilized seed of such plant which is incapable of germination. ${ }^{156}$

Because farmers of industrial hemp grow the plant for its mature stalks, fiber, and oil from the seeds, ${ }^{157}$ it would appear that indeed Congress did exclude industrial hemp from the definition. Generally in a contract drafting environment, if a drafter seeks to exclude certain items from a general

152. Monson, 522 F. Supp. $2 \mathrm{~d}$ at 1191.

153. Id. at $1198 ; 21$ U.S.C. $\S 802(16)$.

154. Monson, 522 F. Supp. $2 d$ at 1191.

155. 21 U.S.C. $\$ 812$ (c)(Schedule I)(c)(10).

156. Monson, 522 F. Supp. $2 d$ at $1198 ; 21$ U.S.C. $\$ 802(16)$.

157. See generally, RICHARD LAWRENCE MILLER, HEMP AS A CROP FOR MisSOURI FARMERS: MARKETS, ECONOMICS, CULTIVATION, LAW (1991), available at www.druglibrary.org/ olsen/hemp/crop/hemp-01.html. 
definition the drafter would do so with an exception to the rule. Thus, anything falling within the exception is considered excluded from the rule, and the exclusion trumps when it comes to ambiguities. Hemp opponents argue it is impossible to grow the mature stalks of the hemp plant without simultaneously growing "all parts of the plant Cannabis sativa L." "158 While this is true, Congress put the mature stalks, fiber, and oil in an exception to the general definition. Therefore, from a contract drafting perspective, the mature stalks, fiber, and oil were not intended to be part of the definition of marijuana. Nevertheless, federal regulatory authorities and the courts continue to enforce the CSA's definition of marijuana as prohibiting the growth of industrial hemp. ${ }^{159}$

\section{B. Kentucky Law and Feasibility}

Kentucky is another state that is trying to pass legislation authorizing the production of industrial hemp. ${ }^{160}$ On January 19, 2012, twelve House members signed on to Kentucky's House Bill 286, which promotes industrial hemp production in Kentucky. ${ }^{161}$ While legislators admit that federal rules still regulate, and therefore Kentucky would still need a federal permit to begin production, Agriculture Commissioner James Comer says, "passage of a legalization bill would provide an impetus to push for a needed federal permit for Kentucky to be a pilot program."162

Kentucky has been the focus of several feasibility studies on industrial hemp viability in the region. ${ }^{163}$ This is partly because

Before hemp cultivation was outlawed, it had been a major crop in Kentucky and grew well in the climate. In the 1800 s, Kentucky regularly accounted for one half of the industrial hemp production in the United States (Hopkins, 1951). The climate, soil, and growing season in Kentucky also make the state a superior location for growing certified hemp seed to be planted by farmers raising an industrial hemp crop. ${ }^{164}$

158. 21 U.S.C. $\S 802(16)$.

159. Monson, 522 F. Supp. $2 \mathrm{~d}$ at 1198.

160. Gregory A. Hall, Industrial Hemp Bill Gains Support; 12 Members of House Sign On, COURIER-JOURNAL (Jan. 20, 2012), available at http://www.courier-journal.com/ article/20120119/BUSINESS/301190069/industrial-hemp-legalization.

161. Id.

162. Id.

163. See generally Vantreese, supra note 26; Thompson, et al., supra note 4, at iii.

164. Thompson, et al., supra note 4 , at iii. 
As Kentucky's tobacco industry continues its decline, ${ }^{165}$ the state looks for other sources to replace their primary cash crop and diversify their industries. ${ }^{166}$

In response to the declination of Kentucky's cash crop industry, the Center for Business and Economic Research in Kentucky conducted a study analyzing the market potential and feasibility of industrial hemp growth in Kentucky. ${ }^{167}$ The study specifically addresses issues regarding the economic impact an industrial hemp industry would have in Kentucky with regard to prices and profitability for Kentucky farmers, potential markets for sales, costs to grow and turn industrial hemp into viable products, and potential job growth in the state. ${ }^{168}$

First, regarding prices and profitability for Kentucky farmers, the study found that growing industrial hemp could result in varying profit depending on the end product for which the plant was grown. ${ }^{169}$ The study found that farmers growing industrial hemp exclusively for the production of straw could earn a profit of approximately $\$ 320$ per acre; if growing for grain only, farmers could expect a return of $\$ 220$ per acre; and if growing to produce certified seed for use by other farmers, Kentucky farmers could expect a profit of $\$ 600$ per acre. ${ }^{170}$

Next, the study showed that there are many markets for Kentucky's hemp products. Specialty niche markets were cited as particularly profitable, specifically animal bedding, paper, food, and oil. ${ }^{171}$ Additionally, the study touted a future market feasibility for "automobile parts, replacements for fiberglass, upholstery, and carpets." 172 After going through a detailed analysis of each feasible hemp market, the study concluded that "there may be demand for up to 100,000 tons of industrial hemp fiber each year. This tonnage suggests that there would be a need to cultivate up to 82,000 acres of industrial hemp for straw or straw and grain each year."173 While the study is a bit dated, these numbers suggest that industrial hemp is definitely a viable crop for Kentucky.

The study goes on to analyze costs associated with cultivation and processing. ${ }^{174}$ While the costs associated with cultivating industrial hemp in Kentucky are relatively low because the plant requires little to no pesticides

165. John I. Gilberbloom, Preface to Dr. Eric C. Thompson, et al., Economic Impact of Industrial Hemp in Kentucky, CTR. FOR BUS. AND ECON. RESEARCH, UNIV. OF KY., at i (1998).

166. Id.

167. See Thompson, et al., supra note 4 at iii.

168. Id. at iii.

169. Id. at iv.

170. Id.

171. Id. at iii.

172. Id.

173. Thompson, et al., supra note 4 at 46 .

174. Id. at 47. 
or fertilizers, ${ }^{175}$ there is some concern about transportation costs because industrial hemp is bulky and heavy. ${ }^{176}$ "Short of locating an industrial hemp processing facility in Kentucky, it may be possible to process industrial hemp using modified tobacco processing equipment. However, this might not be as cost-effective as using equipment designed for decorticating industrial hemp." ${ }^{177}$ The possibility of using existing processing equipment for hemp processing is a promising idea. Much of the concern regarding industrial hemp production revolves around processing costs and the lack of specialized equipment, specifically a decorticator, ${ }^{178}$ to process the hemp.

The last factor the Kentucky study focused on was jobs. ${ }^{179}$ In America today jobs are a constant focus and source of concern. One of the points proponents of industrial hemp make is that the legalization of the plant will create jobs. ${ }^{180}$ This study examined that assertion and found that if

Kentucky again becomes the main source for certified industrial hemp seed in the United States [the economic impact] is estimated at 69 full-time equivalent jobs and $\$ 1,300,000$ in worker earnings. The total economic impact in Kentucky, assuming one industrial hemp processing facility locating in Kentucky and selling certified seed to other growers, would be 303 full-time equivalent jobs and $\$ 6,700,000$ in worker earnings. If two processing facilities were established in Kentucky, industrial hemp would have an economic impact of 537 fulltime equivalent jobs and $\$ 12,100,000$ in worker earnings. If one processing facility and one industrial hemp paper-pulp plant were established in Kentucky, industrial hemp would have an economic impact of 771 full-time equivalent jobs and $\$ 17,600,000$ in worker earnings." 181

These estimates are based on production in certified seed, fiber, and grain industries only. ${ }^{182}$ The study does not include the hemp food industry, ${ }^{183}$ nor

175. Id. at ii.

176. Id. at i.

177. Id. at 9 .

178. Kevin W. McCarty, California: Hemp to Potentially Replace Reliance on Fossil Fuels, DaILY NEXus (Apr. 18, 2011), http://dailynexus.com/2011-04-18/hemp-potentiallyreplace-reliance-fossil-fuels/. A decorticator is a machine that strips fiber from plants, separating it from pulp. Id.

179. Thompson, et al., supra note 4 , at iii.

180. Id. at iv.

181. Id.

182. Id. at 50 .

183. Id. at 52. 
the hemp fuel industry ${ }^{184}$ in its estimates, but it is revealing that job creation, profitability, market penetration, and cultivation is possible in the Midwest region of the United States. ${ }^{185}$

\section{INDUSTRIAL HEMP IN INDIANA}

Despite industrial hemp's potential for success in the Midwest, ${ }^{186}$ Indiana is not among the states that have passed legislation allowing for the growth and production of industrial hemp and hemp related products. However, as a result of a policy study on the effects of current marijuana law held in the summer of 2011, Senator Karen Tallian has introduced Senate Bill 347 (SB347). ${ }^{187}$ SB347 is primarily a decriminalizing effort related to marijuana criminal offenses. ${ }^{188}$ However, Senator Tallian says she plans to propose an amendment to the bill, which would allow the production of industrial hemp. ${ }^{189}$ Currently, Indiana's definition of marijuana encompasses industrial hemp in the same way that the Controlled Substances Act does. ${ }^{190}$ Indiana Code $\S 35-48-1-16$ states:
"Marijuana" means any part of the plant genus Cannabis whether growing or not; the seeds thereof; the resin extracted from any part of the plant, including hashish and hash oil; any compound, manufacture, salt, derivative, mixture, or preparation of the plant, its seeds or resin. It does not include the mature stalks of the plant; fiber produced from the stalks; oil or cake made from the seeds of the plant; any other compound, manufacture, salt, derivative, mixture, or preparation of the mature stalks (except the resin extracted therefrom); or the sterilized seed of the plant which is incapable of germination. ${ }^{191}$

If Indiana decides to pass SB347, then the state would need to amend its Code to first change the definition of marijuana so that it is clear that it only refers to marijuana the drug. Then, Indiana would need to write a new

184. Thompson, et al., supra note 4 at ii.

185. Id. at 55.

186. Id.

187. Karen Tallian, Tallian Lays Out Next Steps for Marijuana Policy Legislation, THE BRIEFING ROOM (Jan. 23, 2012), http://insendems.wordpress.com/2012/01/23/tallian-laysout-next-steps-for-marjiuana-policy-legislation/.

188. Id., see also, 2012 ind. S.B. 347, 2nd Regular Session, available at http://www.in.gov/ apps/lsa/session/billwatch/billinfo?year=2012\&request=getBill\&docno=347.

189. Tallian, supra note 187.

190. Kentucky Cooperative Extension Service, Industrial Hemp - Legal Issues, CroP Diversification BIOFUEL RESEARCH EDUCATION CENTER (2012).

191. IND. CODE ANN. 35-48-1-19 (West 2011). 
definition for industrial hemp. It is important to have two separate definitions so that there is no mistaking the two versions of the same plant species. Alternatively, a better option would be to pass legislation specifically and solely aimed at allowing the emergence of an industrial hemp industry in Indiana. The biggest battle industrial hemp activists face is the common confusion between marijuana and industrial hemp. ${ }^{192}$ Any mention of hemp immediately conjures an image and association with its psychoactive cousin, but the two are very different. ${ }^{193}$ By acknowledging their differences, and passing separate legislation, Indiana can help distinguish the two and demonstrate to society that there is a difference.

With industrial hemp legislation Indiana's industries would explode. Industrial hemp is so versatile, the introduction of it into numerous industries would lower costs in those industries in addition to improving the overall environment. ${ }^{194}$ The Indiana automotive industry is already aware of the benefits of hemp as a natural fiber for car materials; ${ }^{195}$ this industry could benefit further by introducing hemp fiberglass for other car parts or hemp composites in the same way that "BMW, Chrysler, Ford, GM, Honda, Volkswagen and virtually all European car makers have begun using hemp based composites for panel and linings. ${ }^{, 196}$ Currently Indiana automakers must import the hemp products for use in their applications, but if Indiana were to legalize industrial hemp the revenue and jobs could be kept at home. Additional industries that would benefit from an industrial hemp industry in Indiana are the paper industry, food industry, body care products industry, and clothing industry. ${ }^{197}$ All of these industries currently import hemp for inputs into other Indiana-made products. ${ }^{198}$

\section{BIOFUEL IN INDIANA}

While the potential impact of an industrial hemp industry is large for most Indiana industries, the primary reason that Indiana should legalize industrial hemp is because doing so would be extremely beneficial to its economy, specifically in the area of biofuel. Indiana is committed to a thriving biofuel industry. ${ }^{199}$ Since its creation in 2005 , the Indiana

192. David P. West, Hemp and Marijuana: Myths and Realities, NORTH AMERICAN HEMP CounCIL (1998).

193. Id.

194. Thompson, et al., supra note 4, at ii.

195. Hansen, supra note 131.

196. Hemp Facts and Uses, MEDICAL CANNABIS SPAIN, http://www.cannabis-spain.com/ cannabis-hemp.htm (last visited Aug. 18, 2013).

197. Indiana Hemp \& Cotton Recycled Products, ORganIC CONSUMERs Assoc., http://www.organicconsumers.org/state/greenbiz.cfm?state $=\mathbf{I N} \&$ type $=$ hemp (last visited Aug. 18, 2013)

198. Id.

199. Background on Bioenergy and Biofuels, IND. STATE DEP'T OF AG. (2005), available 
Department of Agriculture has made agro-energy one of its strategic goals. ${ }^{200}$ According to the Indiana Department of Agriculture's website:

The Midwest really can be the Middle East of biofuels. [Indiana's] numerous new E85 pumps, more than a dozen new ethanol plants, the world's largest soy biodiesel facility, and the establishment of BioTown are evidence that [the state] won't rest until Indiana is the nation's biofuels capital. Beyond the use of traditional grain for ethanol, Indiana will strive to be a leader in cellulosic ethanol. Cellulosic is the future of biofuels and can be maximized by Indiana's research universities like Purdue. $^{201}$

Currently, because Indiana is one of the nation's leading producers of corn, ${ }^{202}$ it has naturally followed that corn is the main input for the production of agricultural biofuel in the state. ${ }^{203}$ However, funneling corn out of the food supply into the fuel supply has cost Indiana export revenue, ${ }^{204}$ and contributed to the increase in global corn prices. ${ }^{205}$ Before corn was used as an ethanol feedstock, Indiana exported over fifty percent of the corn produced by Indiana farmers. ${ }^{206}$ Now, that "extra" corn is not exported but kept at home to produce biofuel. ${ }^{207}$ In response to the decreased exports Indiana argues that, "as U.S. ethanol production expands, higher U.S. and world corn prices would provide incentives for Brazil and Argentina to expand corn production and compete with U.S. corn in world markets." ${ }^{208}$ However, the price increases caused by taking corn out of the food chain for fuel production has increased food shortages in areas where the food supply is already at risk for insufficiency. ${ }^{209}$ For example, "[b]etween 2002 and 2007, world food prices increased by some 140 percent due to a number of factors including, increased demand for biofuels feedstocks and rising agricultural fuel and fertilizer prices." ${ }^{210}$ As a result of

at http://www.in.gov/isda/biofuels/background.pdf.

200. Economic Growth from Hoosier Homegrown Energy: Indiana's Strategic Energy Plan, IND. OFFICE OF ENERGY DEVELOPMENT (2006), available at http://www.in.gov/ oed/files/Energy_Strategic_Plan_1-2.pdf.

201. Id.

202. Id.

203. Id.

204. Ind. State Dep't Ag., supra note 199.

205. Id.

206. Id.

207. Id.

208. Id.

209. Id.

210. Gunther Fischer, et al., Biofuels and Food Security: Implications of an Accelerated Biofuel Production, INT'L INST. FOR APPLIED SYS. ANALYSIS OFID 18 (Mar. 2009), available 
these higher prices, "in 2008 . . a further 100 million [were added] to the world's undernourished [population]. ${ }^{211}$ While Indiana's argument that increased competition would put downward pressure on the price of corn is true, and it would relieve some of the effects affecting the world food crisis, it is not necessary to remove corn from the food supply, nor subject our corn industry to the risk of lost market share. The introduction of hemp as a feedstock for biofuel would replace the corn that is currently being removed from the food chain to supply biofuel needs. Replacing the corn with hemp would lessen the pressure on global corn prices as the supply of corn increased, ${ }^{212}$ thus helping to alleviate some of the effects third world nations are suffering as a result of the global search for alternative fuel. Furthermore, foregoing export revenue in Indiana is also unnecessary. Indiana has enough farmland ${ }^{213}$ that it is fully capable of maintaining its pre-ethanol corn export levels, while supporting its growing biofuel industry with industrial hemp.

\section{HEMP VS. CORN}

Furthermore, Indiana should switch to producing industrial hemp as a biofuel feedstock because it is a more efficient resource. ${ }^{214}$ There is no question that "corn ethanol is energy efficient." 215 It has "an energy ratio of 1.34 [, which means] for every BTU dedicated to producing ethanol there is a 34 percent energy gain."216 Unfortunately, corn puts high demands on land and water resources, ${ }^{217}$ and producing biofuel from it is energy and resource-intensive. ${ }^{218}$ Industrial hemp, by comparison, because of its high cellulose content has an estimated 540 percent energy gain. ${ }^{219}$ Through Indiana's own research it knows that biofuel from cellulous is the direction the industry is taking. ${ }^{220}$ According to Alan Greenspan, "[c]orn ethanol,

at http://www.ofid.org/publications/PDF/pamphlet/ofid_pam38_Biofuels.pdf

211. Id. at 20.

212. See generally MANKIW, supra note 133.

213. Renewable Energy for America, NAT. RES. DEFENSE COUNCIL, http://www.nrdc.org/ energy/renewables/indiana.asp, (last visited Aug. 17, 2013).

214. Id.

215. Background on Bioenergy and Biofuels, supra note 199.

216. Id.

217. See Economic Research Service, Corn: Background, US DEPT. OF AGRICULTURE, http://www.ers.usda.gov/topics/crops/corn/background.aspx (last visited Aug. 17, 2013) (stating that increased demand for ethanol production has resulted in increased com acreage taken from soybean farms, pasture land, and cotton crops); see also Hamid Farahani and William B. Smith, Irrigation, CLEMSEN.EDU, http://www.clemson.edu/extension/rowcrops/ corn/guide/irrigation.html (last visited Aug. 17, 2013) (explaining water requirements for corn yields).

218. Renewable Energy for America, supra note 213.

219. Bio Fuel Stations, Hemp Bio-Fuel, PANACEA-BOCAF, http://www.panacea-bocaf. org/biofuelstations.htm (last visited Aug. 18, 2013).

220. Economic Growth from Hoosier Homegrown Energy, supra note 200. 
though valuable, can play only a limited role [in energy independence], because its ability to displace gasoline is modest at best. But cellulosic ethanol, should it fulfill its promise, would help to wean us of our petroleum dependence."221

In addition to hemp's high cellulous content, hemp requires little from its growing environment. ${ }^{222}$ It can be grown on land unsuitable for other feedstock crops. ${ }^{223}$ For example, China purports to grow industrial hemp on land that will not displace food crops, or as a rotational crop with soy and wheat. ${ }^{224}$ Furthermore, it can be harvested two or three times per season; ${ }^{225}$ it requires nearly no pesticides or herbicides to thrive; ${ }^{226}$ and it coincidentally leaves the land in better shape than it was in before planting, ${ }^{227}$ thus creating a suitable plot for rotational crops where before there were none. ${ }^{228}$ Moreover, industrial hemp would thrive in Indiana farmland because it "tends to grow best on land that produces high yields of corn. ${ }^{, 229}$

The trend in feedstock crops is now towards cellulous-based ethanol production. ${ }^{230}$ Indiana has recognized that cellulose-based crops are the future for biofuel. ${ }^{231}$ In its strategic outlook, Indiana has dedicated itself to becoming a leader in this field. ${ }^{232}$ With industrial hemp's superiority over other cellulosic plants, ${ }^{233}$ Indiana would surely gain dominance in ethanol production in the United States if it were to employ industrial hemp as the main biofuel feedstock.

\section{ENERgY SECURITY AND ClimATE STEWARDShIP PlATFORM}

As evidence of its commitment to sustainable energy, Indiana has adopted the Energy Security and Climate Stewardship Platform. ${ }^{234}$ The

221. Anthony Crooks, From Grass to Gas, USDA RURAL DevelopMENT, Alan Greenspan, Testimony before Senate Committee on Foreign Relations, June 7, 2006, available at $\mathrm{http}: / / \mathrm{www}$.setamericafree.org/wordpress/?p=93.

222. Fibre Stories, supra note 42.

223. Id.

224. Id.

225. Hemp Defined, supra note 18.

226. Id.

227. Thompson, et al., supra note 4 , at ii.

228. Id.

229. Hemp Defined, supra note 18.

230. Id.; See also Economic Growth from Hoosier Homegrown Energy, supra note 200.

231. Economic Growth from Hoosier Homegrown Energy, supra note 200.

232. Id.

233. Christensen and Smith, supra note 5.

234. Indiana Laws and Incentives for Biodiesel, U.S. DEP'T OF ENERGY, http://www.afdc. energy.gov/afdc/laws/index.php?p=laws\&state $=I N \&$ type=tech\&catid=3251\&print=y $\quad$ (last visited Aug. 18, 2013). See also EnERgy Security \& Climate Stewardship Platform, MIDWESTERN GOVERNORS ASs'N 4, available at http://www.midwesterngovernors.org/ 
Platform establishes shared goals for the Midwestern region as they relate to biofuel, environment, and energy independence. ${ }^{235}$ The goal of the Platform is to "[m]aximize the energy resources and economic advantages and opportunities of Midwestern states while reducing emissions of atmospheric $\mathrm{CO} 2$ and other greenhouse gases." ${ }^{, 236}$ In order to reach its goal, the Platform is committed to meeting various objectives including the implementation of renewable energy technologies, cost-effective energy efficiency, and to "[a]dd economic value and high-paying jobs to the Midwest's energy, agriculture, manufacturing and technology sectors through the development and deployment of lower-carbon energy production and technologies." ${ }^{, 237}$ Some specific strategies to reach the objectives include expanding on the production of biofuels and building a bio-refinery industry. ${ }^{238}$ Regarding transportation and biofuel specifically, the Energy Security and Climate Stewardship seeks to

- Develop the Midwest's capacity for production of biofuels and other low-carbon advanced transportation fuels to advance national energy independence, add value for consumers, revitalize rural economies and the region's manufacturing base, and decrease greenhouse gas emissions.

- Accelerate strategies for improving the efficiency of biofuels production and use, reduce fossil fuel inputs, minimize GHG emissions, decrease water use and strengthen the existing biofuels industry.

- Develop, demonstrate and commercialize a variety of biomass-utilizing technologies and other low-carbon advanced fuels covering a portfolio of energy products and biobased products.

- Pursue innovative opportunities to increase the biofuels supply while improving water quality, soil quality and wildlife habitat.

- Build the infrastructure to allow the bioeconomy to expand. $^{239}$

resolutions/Platform.pdf [hereinafter PLATFORM].

235. Id.

236. PlatFoRM, supra note 234 , at 4.

237. Id.

238. Id. at 5 .

239. Id. at 10-11. 
Industrial hemp is the ideal feedstock to help Indiana meet all of these objectives. An analysis of each one is useful.

1. Develop the Midwest's capacity for production of biofuels and other lowcarbon advanced transportation fuels to advance national energy independence, add value for consumers, revitalize rural economies and the region's manufacturing base, and decrease greenhouse gas emissions. ${ }^{240}$

Currently Indiana's main feedstock inputs are corn and soybean. ${ }^{241}$ These inputs are limited in their capacity because they are both food sources as well. Industrial hemp, on the other hand, contributes to national energy independence by reducing the need for fossil fuel inputs. ${ }^{242}$ It adds values for consumers because it lets food crops be used for food, which reduces the price for that food. It revitalizes rural economies by providing lowskilled agriculture jobs for smaller production farmers. ${ }^{243}$ And hemp is a miracle when it comes to reducing greenhouses gases and leaving the growing environment in a better condition than that in which it was found. . $^{24}$

2. Accelerate strategies for improving the efficiency of biofuels production and use, reduce fossil fuel inputs, minimize GHG emissions, decrease water use and strengthen the existing biofuels industry. ${ }^{245}$

Industrial hemp is an efficient source of biofuel. ${ }^{246}$ Both hemp biomass and hemp seed are available to produce fuel, ${ }^{247}$ whether it is biodiesel or ethanol. ${ }^{248}$ Additionally, hemp's cellulose content far exceeds anything Indiana is currently using as feedstock, managing a $540 \%$ energy gain when processed, which makes it a very efficient biofuel input. ${ }^{249}$ Furthermore, hemp is known to reduce greenhouse gasses, ${ }^{250}$ and requires less water to grow than $\operatorname{cotton}^{251}$ (however, compared to corn the results are mixed).

240. Id. at 10 .

241. Background on Bioenergy and Biofuels, supra note 161.

242. Id.

243. George Brook, National Industrial Hemp Strategy 70 (2008).

244. Thompson, et al., supra note 4 , at ii.

245. PlATFORM, supra note 234, at 10.

246. Castleman, supra note 61.

247. Id.

248. Id.

249. Bio Fuel stations, supra note 219.

250. Angelique van Engelen, Industrial Hemp's Silver Bullet Potential for Reducing Greenhouse Gas, Global Warming Is REAL: Resources for THE CONCERNED CITIZEN, http://globalwarmingisreal.com/2008/05/26/industrial-hemps-silver-bullet-potential-for-reducinggreenhouse-gas/ (last visited Aug. 18, 2013).

251. Castleman, supra note 61. 
3. Develop, demonstrate and commercialize a variety of biomass-utilizing technologies and other low-carbon advanced fuels covering a portfolio of energy products and biobased products. ${ }^{252}$

The addition of industrial hemp as a biofuel source would help diversify Indiana's biofuels portfolio. Additionally, while hemp biofuel is the focus here, the plant is extremely versatile, capable of producing over 25,000 products, ${ }^{253}$ which could fill out Indiana's biobased products portfolio effortlessly.

\section{Pursue innovative opportunities to increase the biofuels supply while} improving water quality, soil quality and wildlife habitat. ${ }^{254}$

Estimates suggest that industrial hemp is capable of producing 1300 gallons of fuel per acre of biomass. ${ }^{255}$ Hemp can be grown in conjunction with corn and soybean feedstock because it is capable of growing on unfarmed land, ${ }^{256}$ or in rotation with other crops. ${ }^{257}$ Alternatively, industrial hemp can easily replace corn and soybean feedstock on currently farmed land because such land is ideal for maximum output. ${ }^{258}$ Any of these growing options would increase the biofuel supply. Furthermore, studies show that growing industrial hemp improves water quality because it requires little to no pesticides, ${ }^{259}$ and it improves soil quality, often leaving it in better condition. ${ }^{260}$ The improvement in water and soil quality would naturally lead to an improvement in wildlife habitat because the environment would be able to support additional wildlife and plants.

\section{Build the infrastructure to allow the bioeconomy to expand. ${ }^{261}$}

Legalizing industrial hemp would increase the biofuel supply, increase exports, as well as provide Indiana with new industries, resulting in increased revenue for the State. The extra revenue received could be reinvested in Indiana's bioeconomy.

252. PLATFORM, supra note 234, at 10.

253. New Billion Dollar Crop, supra note 34.

254. PLATFORM, supra note 234, at 11.

255. All About Hemp, at 1.7, PROJECT HUMANITY EARTH, available at http://www.project-humanity-earth.org/yahoo_site_admin/assets/docs/All-About-

Hemp.70130752.pdf (last visited Aug. 18, 2013).

256. Castleman, supra note 61.

257. Id.

258. Hemp Defined, supra note 18.

259. Thompson, et al., supra note 4, at 53.

260. R.M. Forbes, Industrial Hemp Can Save America, Dally Kos (Sept. 9, 2011), http://www.dailykos.com/story/201 1/09/09/1014706/-Industrial-Hemp-can-save-America.

261. PlATFORM, supra note 234 at 11. 
As for Indiana and many other Midwestern states that have adopted the Energy Security and Climate Stewardship Platform, industrial hemp seems to be an almost perfect answer to their energy needs.

\section{Federal Legalization}

Despite Indiana's potential to become a huge producer of industrial hemp and to take advantage of the opportunities it holds as a biofuel, the State is still limited by the Controlled Substances Act. ${ }^{262}$ Federal law preempts when a federal and state law conflict. ${ }^{263}$ One of the ways for states like Indiana to capitalize on the hemp industry is for Congress to remove industrial hemp from the definition of marijuana in the Controlled Substances Act. According to the Act itself, several factors are considered in making a determination of whether a drug should be removed from a schedule. ${ }^{264}$ Specifically, the Act states:

In making any finding under subsection (a) of this section or under subsection (b) of section 812 of this title, the Attorney General shall consider the following factors with respect to each drug or other substance proposed to be controlled or removed from the schedules:

(1) Its actual or relative potential for abuse.

(2) Scientific evidence of its pharmacological effect, if known.

(3) The state of current scientific knowledge regarding the drug or other substance.

(4) Its history and current pattern of abuse.

(5) The scope, duration, and significance of abuse.

(6) What, if any, risk there is to the public health.

(7) Its psychic or physiological dependence liability.

(8) Whether the substance is an immediate precursor of a substance already controlled under this subchapter. ${ }^{265}$

Ideally, during Congressional review of the proposed legislation, S. 359, Congress will submit industrial hemp to an evaluation using the previously mentioned factors. Doing so should result in a finding that industrial hemp

262. See Controlled Substances Act, Pub. L. No.91-513, Tit. II, Sec. 102(15), 84 Stat. 1242,1244 (codified as amended at 21 U.S.C. $\$ 802(16)$ ).

263. See Altria Group, Inc. v. Good, 555 U.S. 70, 76-77 (2008) ("Article VI, cl. 2, of the Constitution provides that the laws of the United States 'shall be the supreme Law of the Land. . . ' Consistent with that command, we have long recognized that state laws that conflict with federal law are 'without effect."' (citations omitted)).

264. 21 U.S.C. $\$ 811(\mathrm{c})$.

265. Id. 
does not belong as a Schedule I controlled substance. Going through the factors finds that:

(1) Industrial hemp does not have any potential for abuse because it is a commodity, not a drug; ${ }^{266}$

(2) Scientific evidence shows that industrial hemp contains nominal levels of THC, the psychoactive property of marijuana, and cannot cause any narcotic effect; ${ }^{267}$

(3) There is substantial scientific knowledge regarding the absent nature of industrial hemp as a drug, ${ }^{268}$

(4) History shows that Congress did not intend to prohibit farmers from growing industrial hemp, ${ }^{269}$ and there is no current pattern of abuse for industrial hemp;

(5) Again, there is no abuse of the crop;

(6) No direct risk to public health exists. In fact, hemp seeds and hemp oil are optimal sources of nutrients for humans. ${ }^{270}$ However, there is an argument to be made that some people could confuse industrial hemp with its cousin marijuana, ${ }^{271}$ and if so a public health risk may exist, albeit small;

(7) Industrial hemp has not been shown to create any psychic or physiologic dependence,; $; 2$ and

(8) Industrial hemp is not a precursor to any drug because it is not a drug itself. ${ }^{273}$

By this analysis, the factors are in favor of removing industrial hemp from the definition of marijuana under the Controlled Substances Act.

Alternatively, the United States could adopt a regulatory scheme similar to Canada's. Instead of passing regulation to the states as Representative Paul's bill proposes, the federal government could carve out an exception to the Controlled Substances Act, allowing the CSA to be the controlling body of law, yet have a subsection specifically defining and regulating industrial hemp. For instance, Canada maintains cannabis as a Schedule II controlled substance, ${ }^{274}$ defining it as:

266. See Jay Halfon, Industrial Hemp Petition, Resource Conservation Alliance, http://www.woodconsumption.org/alts/petition.html (last visited Aug. 18, 2013).

267. See id.; see also Hemp Defined, supra note 18; Hemp Facts, supra note 2.

268. See Hemp Facts, supra note 2; Halfon, supra note 261.

269. See RENÉE JoHnSON, HeMP AS AN AGRICUltural COMMODITY 11 (2012), available at http://www. fas.org/sgp/crs/misc/RL32725.pdf; Halfon, supra note 261.

270. See Thompson, et al., supra note 4, at 7-8; Hemp Facts, supra note 2; Halfon, supra note 261 .

271. See Hemp Facts, supra note 2; Halfon, supra note 266.

272. See Halfon, supra note 266.

273. Id.

274. See Controlled Drugs and Substances Act, sched. II, S.C. 1996, c. 19 (Can.), available at $\mathrm{http}: / /$ laws-lois.justice.gc.ca/eng/acts/C-38.8/ 
Cannabis, its preparations, derivatives and similar synthetic preparations, including Cannabis resin, Cannabis (marihuana), cannabidiol, cannabinol, nabilone, pyrahexyl, tetrahydrocannabinol; but not including non-viable Cannabis seed, with the exception of its derivatives, and mature Cannabis stalks that do not include leaves, flowers, seeds or branches; and fiber derived from such stalks[.] ${ }^{275}$

While preserving the classification of marijuana, the Controlled Drugs and Substances Act carves out a subsection specifically for industrial hemp ${ }^{276}$ and defines it as:

[T]he plants and plant parts of the genera Cannabis, the leaves and flowering heads of which do not contain more than $0.3 \% \mathrm{THC} \mathrm{w} / \mathrm{w}$, and includes the derivatives of such plants and plant parts. It also includes the derivatives of non-viable cannabis seed. It does not include plant parts of the genera Cannabis that consist of non-viable cannabis seed, other than its derivatives, or of mature cannabis stalks that do not include leaves, flowers, seeds or branches, or of fibre derived from those stalks. ${ }^{277}$

It is interesting to note that the Canadian definition of industrial hemp is similar to the definition adopted by North Dakota ${ }^{278}$ which includes in the definition the distinction regarding the percent of tetrahydrocannabinol allowable. ${ }^{279}$ The federal government, in addition to having Canada as an example for implementation and success of industrial hemp regulations, could also look to the states for various policy rationales behind adoption of the new definition.

When analyzing and creating the new legislation, the United States would be well served by following Canada's method of analysis. The criteria by which Canada evaluated legalization are all important policy considerations for the United States, and are in line with US interests. Specifically, Canada's mandatory criteria that the option chosen: be in conformity with other laws, comply with Canada's international obligations, must not facilitate the production of illicit drugs, and must

275. Id.

276. Industrial Hemp Regulations (Controlled Drugs and Substances Act), sec. 1, SOR/98-156 (Can.), available at http://laws-lois.justice.gc.ca/PDF/SOR-98-156.pdf.

277. Id.

278. See N.D. CENT. Code ANN. § 4-41-01 (West 2011).

279. Id. ("Industrial hemp (cannabis sativa 1.), having no more than three-tenths of one percent tetrahydrocannabinol, is recognized as an oilseed."). 
provide an appropriate means of control ${ }^{280}$ are all concerns of the United States. ${ }^{281}$ Furthermore, the screen criteria adopted by Canada that the option must not hinder trade; not be a burden on government and industry; or that it must not undermine public confidence ${ }^{282}$ are also concerns for the United States. ${ }^{283}$ By following Canada's analysis, the United States has the advantage of comparison, with the ability to determine if Canada's reasoning is applicable to the United States. If so determined, then the United States could simply adopt Canada's regulations without significant change.

Once Congress makes the distinction between marijuana and industrial hemp, the issue of enforcement remains and, in fact, is one of the concerns expressed by law enforcement officials. ${ }^{284}$ The concern is that enforcement would burden local law officials because they would have a hard time distinguishing between hemp and marijuana fields, and people would try to covertly grow marijuana in hemp fields. ${ }^{285}$ However, many countries have no trouble at all with these two issues because the regulatory scheme ensures that locations of hemp farms are clearly registered and known to law enforcement. ${ }^{286}$ Furthermore, covert planting of marijuana in hemp fields would prove disastrous to the marijuana grower because the two strands would cross-pollinate, and the low THC strand, industrial hemp, would win the genetic war causing the marijuana to lose potency. ${ }^{287}$

In Canada, the agency Health Canada furnishes permits and licenses for the growth of industrial hemp; Health Canada also maintains the regulations. ${ }^{288}$ Of course, enforcement belongs to the law enforcement agencies ${ }^{289}$ but the regulations are so strict and exact that police know where and what type of hemp grows in each field, ${ }^{290}$ which alleviates much of the concern with distinguishing between the two strains of Cannabis. Similar to Health Canada's role, the DEA could still be the controlling

280. Regulatory Impact Analysis Statement, Industrial Hemp Regulations, C. Gaz. 1997 pt. I, 3905, 3910 (Can.).

281. See 21 U.S.C. $\S 801$ a(1)-(2).

282. REgULATORY IMPACT ANALYSIS STATEMENT, C. Gaz. 1997 pt. I, at 3910.

283. See e.g. Jonathan Miller, Inside the Movement to Legalize Hemp, THE DAILy BEAST (May 14, 2013), http://www.thedailybeast.com/articles/2013/05/14/inside-the-movement-tolegalize-hemp.html.

284. See KENTUCKY PRESS NEWS SERVICE, Beshear Sides with Law Enforcement over Hemp Legalization, WEKU.FM (Feb. 9, 2013), available at http://weku.fm/post/ beshear-sides-law-enforcement-over-hemp-legalization.

285. West, supra note 12.

286. Id.

287. CRS REPORT, supra note 2 , at 3.

288. See Industrial Hemp Regulations (Controlled Drugs and Substances Act), secs. 1, 8, SOR 98-156 (Can.), available at http://laws-lois.justice.gc.ca/PDF/SOR-98-156.pdf

289. See, e.g., Controlled Drugs and Substances Act, $\S 11$ (1), S.C. 1996, c. 19 (Can.), available at http://laws-lois.justice.gc.ca/PDF/C-38.8.pdf.

290. See West, supra note 12. 
agency for the enforcement of industrial hemp regulations, continuing to have the authority to grant permits to states and individuals wishing to cultivate industrial hemp. Yet, contrary to current practice, permits should not be unreasonably withheld. Nor would they need to be because the adopted regulations should be strict, and potential growers should have to abide by them absolutely. This is especially important in the beginning until the various kinks associated with all regulatory change are worked out.

While the US government's biggest concern regarding industrial hemp regulation is how to tell the difference between industrial hemp and marijuana, ${ }^{291}$ Canada is not so troubled. Its solution to the uncertainty is to require GPS coordinates of each growing plot, and require within each plot the coordinates of each type of hemp output grown. ${ }^{292}$ Therefore, officials know exactly what is planted where. Furthermore, Canada requires a minimum plot of 0.4 hectares of hemp grown for seed or a minimum of four hectares for hemp grown for fiber to help distinguish between fields of industrial hemp and illegal fields of marijuana. ${ }^{293}$

Another very important part of Canada's hemp regulation, and crucial to the distinction between marijuana and industrial hemp, is Canada's seed regulations. ${ }^{294}$ Under paragraph 14 , a person licensed to grow industrial hemp may grow only seed that is approved to grow in their specific region; the seed must be the seed that is listed on the grower's license; and the seed must be "an approved cultivar referred to in subsection (1) [and] must be of a pedigreed status, as defined in subsection 2(2) of the Seeds Regulations." 295 Pedigreed status under the Seeds Regulations "means that the seed is of foundation status, registered status or certified status or the seed is approved by the Association as being breeder seed or select seed."296 Additionally, Canada has created a list of approved cultivars. ${ }^{297}$ The approved cultivars are seeds that are from

a variety of hemp that is recognized by the Canadian Seed

291. Tim Johnson \& Adam Silverman, More States Want Federal Government's OK to Grow Hemp, USA TODAY (Nov. 3, 2011, 1:52 AM), http://www.usatoday.com/news/nation/ story/2011-11-06/hemp/51042146/1?csp=34news.

292. See JOHNSON, supra note 269 , at 3 .

293. Can. Seed Growers Ass'n, Circular 6: Canadian Regulations and Procedures for Pedigreed Seed Crop Production $\S 11.2 .10$ (a) (2013), available at http://www.seedgrowers. ca/pdfs/Circ\%206\%20March\%2013\%202013\%20Update/Circ6_Complete_Rev01.8-2013_ 20130123.pdf.

294. Industrial Hemp Regulations, SOR/98-156, §18 (Can.).

295. Id. § 14.

296. Seeds Regulations C.R.C., c. 1400 (Can.).

297. Health Canada, Healthy Environments and Consumer Safety Branch, List of Approved Cultivars for the 2012 Growing Season (2012), available at http://www.hcsc.gc.ca/hc-ps/alt_formats/hecs-sesc/pdf/pubs/precurs/list_cultivars-liste2012/list_cultivarsliste2012-eng.pdf. 
Growers' Association, the Canadian Food Inspection Agency or the Organisation for Economic Co-operation and Development; and ... the Minister has reasonable grounds to believe that the cultivar is likely to produce a plant that will contain $0.3 \% \mathrm{THC} \mathrm{w} / \mathrm{w}$ or less in its leaves and flowering heads when it is cultivated in the region of Canada for which it is to be designated. ${ }^{298}$

The seeds on the approved cultivars list may or may not require further testing, depending on the seed. ${ }^{299}$ If the seeds do require further testing to determine their THC concentration, then farmers must "have samples of the industrial hemp collected in accordance with the methods set out in the Manual; and .. . have the samples tested at a competent laboratory using analytical procedures set out in the Manual." ${ }^{300}$ Canada has taken substantial steps to ensure that the seeds grown by industrial hemp farmers are approved, certified, and contain no more than $0.3 \%$ THC content. $^{301}$

The United States already indirectly acknowledges and approves of the Canadian regulations. Evidence of this is the fact that the United States imported nearly $\$ 8.6$ million dollars of raw hemp products from Canada in $20100^{302}$ This number includes raw inputs only, and does not include finished products such as hemp food, textiles, or body care products. ${ }^{303}$ If Canada did not have such strict regulations regarding THC content, both in their approved cultivars and in the testing of some varieties, the United States would not allow any imports of hemp products into the country. ${ }^{304}$ The government simply needs to take one step further and implement licensing and enforcement regulations so that the American economy can fully benefit from an industrial hemp industry.

Another concern for opponents of an industrial hemp industry is that regulation of industrial hemp would be cost prohibitive. ${ }^{305}$ Admittedly, at first it will likely be expensive to regulate, but there are always additional

298. SOR/98-156, §39(1)(a), (b) (Can.).

299. See Health Canada, supra note 297.

300. Industrial Hemp Regulations, SOR/98-156, §16 (Can.).

301. See generally, id.

302. Canadian Hemp: Nature's Wonder Fibre, AGRIC. AND AGRI-Food CAN. (Aug. 10, 2011), http://www.marquecanadabrand.agr.gc.ca/fact-fiche/pdf/4687-eng.pdf. (The conversion rate on 3/23/12 was 1 Canadian dollar to 1.002 U.S. dollars) See Canadian Dollars (CAD) to US Dollars (USD) Exchange Rate for March 23, 2012, ExCHANGE-RATES.ORG, http://www.exchange-rates.org/Rate/CAD/USD/3-23-2012.

303. Id.

304. See generally, Ray Hansen, Industrial Hemp Profile, AGRICULTURAL MARKETING RESOURCE CENTER, http://www.agmrc.org/commodities_products/fiber/industrial-hempprofile/ (last updated Aug. 2012).

305. See West, supra note 12. 
expenses when implementing a new system. One cannot simply look at the costs associated with change. It is also necessary to examine the beneficial results that the change will bring. Weighing the costs and benefits against each other will undoubtedly show that the benefits of regulating industrial hemp will far outweigh the costs the change will incur. Moreover, after time, efficiency will increase and costs will subsequently decrease, while the benefits of an industrial hemp industry will remain.

\section{CONCLUSION}

Ultimately, Indiana's potential to be the leader in the biofuel industry depends largely on the federal government's classification of industrial hemp. Once Congress distinguishes between marijuana and industrial hemp, empowering regulation with the Drug Enforcement Agency under a scheme similar to Canada's, the states would be able to go forward with their own regulations to comply with federal regulations. Indiana would then be able to amend its own definition of Cannabis to separate marijuana from industrial hemp, similar to the actions taken by other states such as North Dakota and Kentucky, which have authorized the cultivation and production of hemp and hemp-based products. Acknowledging that legislators in Indiana have introduced legislation seeking to decriminalize marijuana with the intent to amend it in the future to include industrial hemp, a better option would be to introduce legislation specifically for the regulation of industrial hemp. A separate law would ensure that the public, and government, recognizes the difference between industrial hemp and marijuana.

The growth of industrial hemp would support and enhance Indiana's renewable biofuel industry. Industrial hemp cultivation for biofuel feedstock would have a positive effect on Indiana's export revenue by allowing excess corn, which is no longer being grown for fuel, to be exported as it used to be. These exports, in turn, will relieve some of the pressure on corn prices as more corn enters the market for food, which will result in decreased shortages in the world's food supply. Cultivation would also satisfy Indiana's goals under the Energy Security and Climate Stewardship Platform. ${ }^{306}$

Indiana industry is being jeopardized by the federal government's refusal to acknowledge the many uses and benefits of the industrial hemp plant because they think "commercial cultivation would increase the likelihood of covert production of high-THC marijuana and send the wrong message to the American public concerning the government's position on drugs. ${ }^{307}$ If the United States simply adopted a regulatory/licensing scheme

306. See generally Platform, supra note 234.

307. Johnson \& Silverman, supra note 291. 
similar to Canada's and educated people on the difference between marijuana and industrial hemp, the American public would be informed and understand that industrial hemp can provide so many benefits from food to fuel for our amazing country. 
